Journal of medical \& pharmaceutical Sciences

Volume (5), Issue (2) : 30 Jun 2021

P: $13-34$
AJSRP

ISSN: 2522-333X
مجلة العلوم الطبية والصيدلانية

المجلد (5)، العدد (2) : 30 يونيو 2021 م

ص: 13 - 34

\title{
Surgical outcome of management of perforated peptic ulcer
}

\section{Al-Gumhori General Hospital, Sana-Yemen, From January 2017 to January 2020}

\author{
Abdullah Mohammed Abdulwally \\ Aden University || Yemen \\ Yasser Abdurabo Thabet \\ Faculty of Medicine || Dhamar University || Yemen \\ Moahmmed Noman Albadani \\ Surgical Department || Al-Jamhouri Hospital || Yemen
}

\section{Ali Lotf Alamri}

Althawra Hospital || Yemen

Abstract: Background: Perforated peptic ulcer (PPU) is a common life-threatening surgical emergency. Discovery of $H$. pylori (1985) changed the concept of the management of peptic ulcer. Now-a-days reduction in gastric acid production with proton pump inhibitors along with eradication of H. pylori is recommended.

Objective: to analysis the surgical outcome for management of perforated peptic ulcer in Al-gomhuri Hospital during 20172020.

Methods: Clinically suspected cases of PPU were confirmed by radiological and laboratory investigation. These patients were subjected to exploratory laparotomy with Graham's omental patch repair after adequate fluid resuscitation with optimal hemodynamic status with peritoneal drainage Postoperatively these patients kept in SICU and closely monitored. Data were collected, tabulated and analyzed.

Results: 62 cases enrolled; Male patients were predominant than female in a ratio of 60:2. Age ranges from 20 to $>60$ years. Majority of the patients belongs to the age group 30-40 years of age. The morbidity and mortality rates were (20\%) and (3.2\%) respectively.

Conclusions: Adequate fluid resuscitation with optimal hemodynamic status and optimal kidney function is the key to decrease morbidity and mortality rates. Simple closure with omental patch followed by $\mathrm{H}$. pylori eradication is effective with excellent outcome in most of survivor despite of late presentation. Definitive surgery for ulcer recurrence is no more done except in special situation.

Keywords: Perforated peptic ulcer, Peritonitis, Graham's omental patch.

$$
\begin{aligned}
& \text { النتيجة الجراحية لتدبير القرحة الهضمية المثقوبة } \\
& \text { (مستشفى الجمهوري العام، صنعاء - اليمن، من يناير } 2017 \text { إلى يناير 2020) } \\
& \text { عبد الله محممد عبد الولي } \\
& \text { جامعة عدن || اليمن }
\end{aligned}
$$




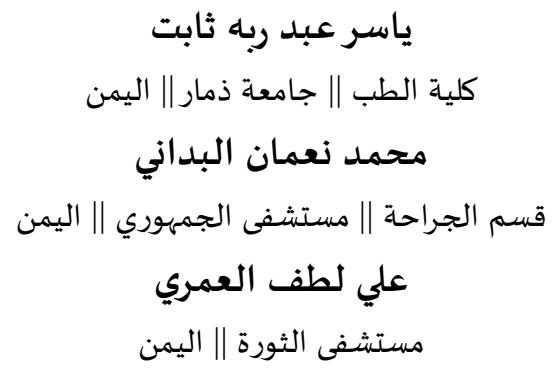

المستخلص: خلفية الدراسة: القرحة الهضيمية المثقوبة (PPU) هي حالة طارئة جراحية تهدد الحياة بشكل شائع. أدى اكتشاف الحلزونية البوابية (1985) إلى تغيير مفهوم إدارة القرحة الهضمية. يوصى بتقليل إنتاج حمض المعدة الآن بعد يوم باستخدام مثبطات مضخة البروتون جنبًا إلى جنب مع القضاء على الحلزونية البوابية.

هدف الدراسة: تحليل النتيجة الجراحية لتدبير القرحة المعوية المثقبة في مستشفى الجمهورية خلال 2017-2020. الطريقة: تم تأكيد الحالات المشتبه بها سريريًا من PPU عن طريق الفحص الإشعاعي والمختبر. تعرض هؤلاء المرضى لاستئصال البطن الاستكشافي مع إصلاح رقعة غراهام بعد إنعاش السوائل بشكل كافٍ مع حالة ديناميكية الدم المثلى مع التصريف البريتوني بعد الجراحة، احتفظ هؤلاء المرضى في وحدة العناية المركزة المركزة للأطفال وخضعوا للمراقبة الدقيقة تم جمع البيانات وتبويها وتحليلها. النتائج: تم تسجيل 62 حالة.. كان المرضى الذكور هم السائد من الإناث بنسبة 60: 2. يتراوح العمر من 20 إلى 60 >سنـة. تنتمي غالبية

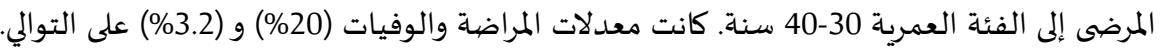
الاستنتاجات: إن الإنعاش الملائم بالسوائل مع حالة الدورة الدموية المثلى ووظيفة الكلى المثلى هو المفتاح لتقليل معدلات الماتلى المراضية والوفيات. إن الإغلاق البسيط بالرقعة المثقوبة متبوعًا باستئصال الحلزونية البوابية فعال مع نتائج ممتازة في معظم الناجين على الرغم

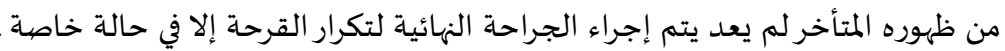
الكلمات المفتاحية: القرحة الهضيمية المثقبة، التهاب الصففاق، رقعة غراهام الثُرْبيَّة

\section{Introduction}

Peptic ulcer perforation is a serious and life threatening complication which affects $2-10 \%$ of peptic ulcer patients on average. ${ }^{(1,2)}$ The overall mortality of Perforated peptic ulcer (PPU) is $10 \%$ ranging from $1.3-20 \%$ in different studies. ${ }^{(3-5)}$ Being a life threatening complication of peptic ulcer, these patients need special attention with prompt fluid resuscitation and appropriate management, if better outcome is desired. $^{(5,6)}$

Since the 1st description of surgery for acute PPU, many techniques have been recommended for closure of perforation. Recent advance in antiulcer therapy have shown that simple closure of perforation with omental patch or plug followed by eradication of Helicobacter pylori is simple and safe option in many centers. It has changed the old trend of definitive therapy like truncal vagotomy and drainage procedure as it was associated with high morbidity and mortality $(13 \%) .{ }^{(7)}$ This study was done to analyze the outcome of the patients operated for PPU condition.

Peptic ulcer disease can involve the stomach or duodenum. Gastric and duodenal ulcers usually cannot be differentiated based on history alone, although some findings may be suggestive.

epigastria pain is the most common symptom of both gastric and duodenal ulcers, characterized by a gnawing or burning sensation and that occurs after meals_classically, shortly after meals with gastric ulcers and 2-3 hours afterward with duodenal ulcers. 
In uncomplicated peptic ulcer disease, the clinical findings are few and nonspecific. ${ }^{\left({ }^{\prime \prime} \text { “Alarm }\right.}$ features" that warrant prompt gastroenterology referral ${ }^{[1]}$ include bleeding, anemia, early satiety, unexplained weight loss, progressive dysphagia or odynophagia, recurrent vomiting, and family history of gastrointestinal (Gl) cancer. Patients with perforated peptic ulcer disease usually present with a sudden onset of severe, sharp abdominal pain.

(7) In most patients with uncomplicated peptic ulcer disease, routine laboratory tests usually are not helpful; instead, documentation of peptic ulcer disease depends on radiographic and endoscopic confirmation. Testing for $\mathrm{H}$ pyloriinfection is essential in all patients with peptic ulcers. Rapid urease tests are considered the endoscopic diagnostic test of choice. Of the noninvasive tests, fecal antigen testing is more accurate than antibody testing and is less expensive than urea breath tests but either is reasonable. A fasting serum gastrin level should be obtained in certain cases to screen for Zollinger-Ellison syndrome.

Upper Gl endoscopy is the preferred diagnostic test in the evaluation of patients with suspected peptic ulcer disease. Endoscopy provides an opportunity to visualize the ulcer, to determine the presence and degree of active bleeding, and to attempt hemostasis by direct measures, if required. Perform endoscopy early in patients older than 45-50 years and in patients with associated so-called alarm features. (9)

Most patients with peptic ulcer disease are treated successfully with cure of $H$ pylorinfection and/or avoidance of nonsteroidal anti-inflammatory drugs (NSAIDs), along with the appropriate use of antisecretory therapy. In the United States, the recommended primary therapy for $H$ pyloriinfection is proton pump inhibitor (PPI)-based triple therapy. These regimens result in a cure of infection and ulcer healing in approximately $85-90 \%$ of cases. ${ }^{(9)}$ Ulcers can recur in the absence of successful $H$ pylorieradication.

In patients with NSAID-associated peptic ulcers, discontinuation of NSAIDs is paramount, if it is clinically feasible. For patients who must continue with their NSAIDs, proton pump inhibitor (PPI) maintenance is recommended to prevent recurrences even after eradication of $H$ pylori. ${ }^{(10,11)}$ Prophylactic regimens that have been shown to dramatically reduce the risk of NSAID-induced gastric and duodenal ulcers include the use of a prostaglandin analog or a PPI. Maintenance therapy with antisecretory medications (eg, $\mathrm{H} 2$ blockers, PPIs) for 1 year is indicated in high-risk patients.

The indications for urgent surgery include failure to achieve hemostasis endoscopically, recurrent bleeding despite endoscopic attempts at achieving hemostasis (many advocate surgery after two failed endoscopic attempts), and perforation.

Patients with gastric ulcers are also at risk of developing gastric malignancy. 
Risk factors predisposing for perforated peptic ulcer disease

A

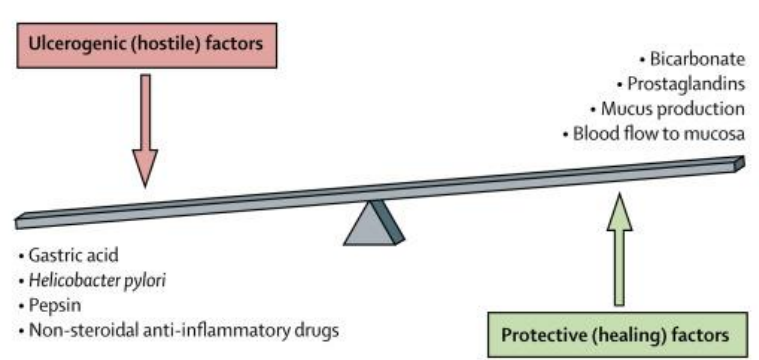

B

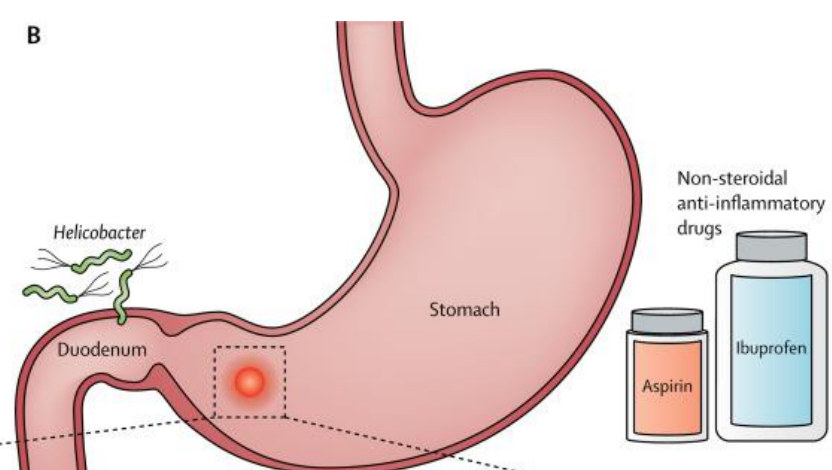

$\mathrm{C}$
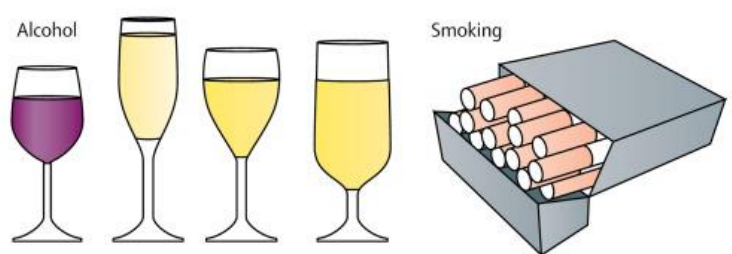

Drugs and medications
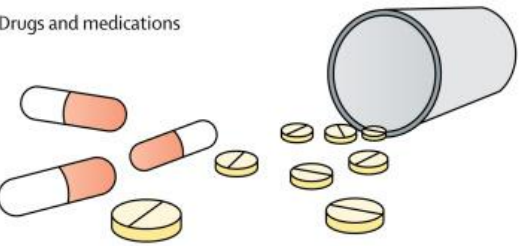

D

$\mathrm{E}$

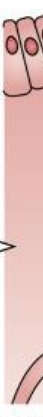

$\mathbf{F}$

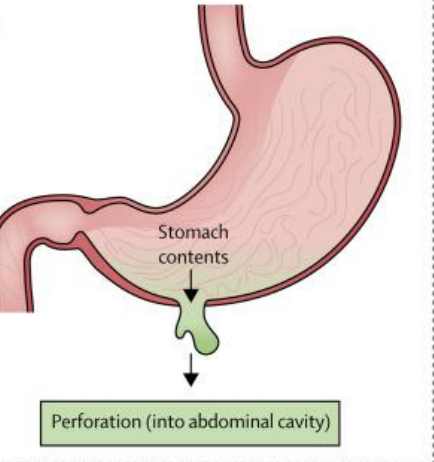

${ }^{(12)}$ Figure (1)

\section{Non-steroidal anti-inflammatory drugs (including aspirin)}

Inhibitors of synthesis of prostaglandins. Leads to increased production of gastric acids and reduced mucus secretion.

\section{Smoking}

Smoking inhibits secretion of bicarbonate. Nicotine stimulates secretion of acid. Strongly linked to perforated peptic ulcer in people younger than 75 years of age.

\section{Helicobacter pylori}

Most common in cohorts of young men (usually $<40$ years) with perforated duodenal ulcers in low-income and middle-income countries. Different virulence strains might be of relevance in genesis. 
Marginal ulcer after bariatric surgery

Probably due to ischemia of the anastomosis.

\section{Fasting}

Several reports of perforated peptic ulcers during Ramadan. Fasting leads to increased acid production on an empty stomach.

\section{Crack cocaine, cocaine, and methamphetamine use}

Can lead to intense vasoconstriction followed by ischemia. Can also cause thrombus formation and necrosis of mucosa.

\section{Zollinger-Ellison syndrome (gastrinoma)}

Rare; risk for recurrent and multiple ulcers. Increased secretion of gastrin causes increased and persistent hydrochloric acid secretion in the stomach and duodenum, with ulceration and potential perforation of the gastrointestinal wall.

\section{Stress ulcers}

Ulcers in critically ill patients (burns, trauma, etc) in intensive care; most often complicated by bleeding but occasionally perforation occurs. Difficult diagnosis in patients who are sedated or those on artificial ventilation.

\section{Steroids}

Affects inflammatory cascade, including prostaglandin synthesis. Can blunt signs of peritonitis.

Salt

High consumption increases acidity in the stomach.

\section{Alcohol}

High consumption is especially linked to risk of bleeding ulcers, but also to increased risk of perforation.

\section{Chemotherapy with bevacizumab}

VEGF inhibition has increased risk of gastrointestinal perforations; can increase with more widespread use 


\section{Clinical assessment and diagnosis}

Patients with perforated peptic ulcer might present with severe, sudden-onset epigastric pain, which can become generalised. The peritonitis resulting from acid exposure can present as abdominal board-like rigidity. The clinical picture might be less clear in obese patients, immunocompromised individuals, patients on steroids, those with a reduced level of consciousness, elderly people, and children. In these situations, the clinical history and examination might be non-specifi c, prompting additional imaging and laboratory studies to rule out differential diagnoses. ${ }^{(13)}$ Only two-thirds of patients present with frank peritonitis, which might partly explain the diagnostic delay in some patients.

${ }^{(14,15)}$ During clinical assessment, several differential diagnoses should be considered, but, most importantly, a ruptured abdominal aortic aneurysm or acute pancreatitis must be excluded — the former because of its high mortality rate if unrecognized and treatment is delayed, and the latter because its management is mainly non-operative.

Diagnostic imaging might have to be delayed pending resuscitation in critically ill patients. Those presenting with generalized peritonitis with or without signs of sepsis will usually be directed straight to the operating theatre. Notably, mortality increases with every hour by which surgery is delayed.

\section{Laboratory markers and radiological imaging}

Laboratory markers are not diagnostic for perforated ulcers. However, they do help doctors to estimate the inflammatory response and assess organ function, and to exclude relevant differential diagnoses, such as acute pancreatitis.

Blood cultures should be taken early, before broad-spectrum antibiotics are started, although antibiotic treatment must not be delayed. ${ }^{(16)}$ An arterial blood gas can serve as an adjunct to clinical assessment of vital functions (eg, $\mathrm{pH}$, lactate, base excess, and oxygen saturation) and can measure the degree of metabolic compromise in patients with sepsis. ${ }^{(17)}$ Gastroduodenal perforation is the most common cause of pneumoperitoneum, together with perforated diverticulitis (in high-income countries) and typhoid or salmonella enteritis perforations (in low-income and middle-income countries). ${ }^{(18,19)}$ Thus, demonstration of so-called free air on radiological examination is highly indicative of a perforated viscus organ. An erect chest radiograph or an upright abdominal radiograph is easy, cheap, and quick to do and can be diagnostic. However, its sensitivity is only $75 \%$ and it might not show the exact cause of pneumoperitoneum. Reports on the diagnostic use of ultrasonography exist, but the approach has not gained widespread use and is investigator dependent. 


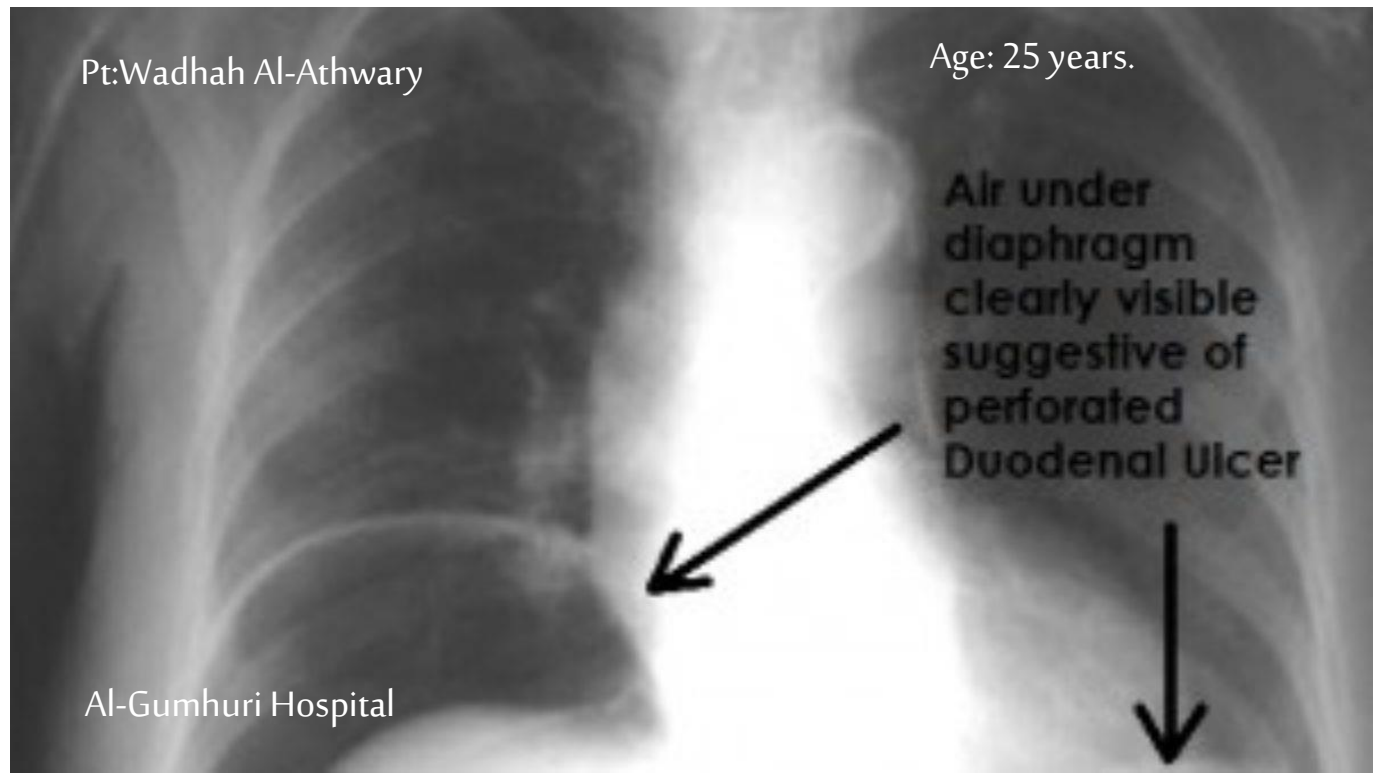

Figure (2)

An abdominal CT scan has become the imaging modality of choice because of its superior sensitivity (reportedly 98\%) and its additional value in assessment for other differential diagnoses.

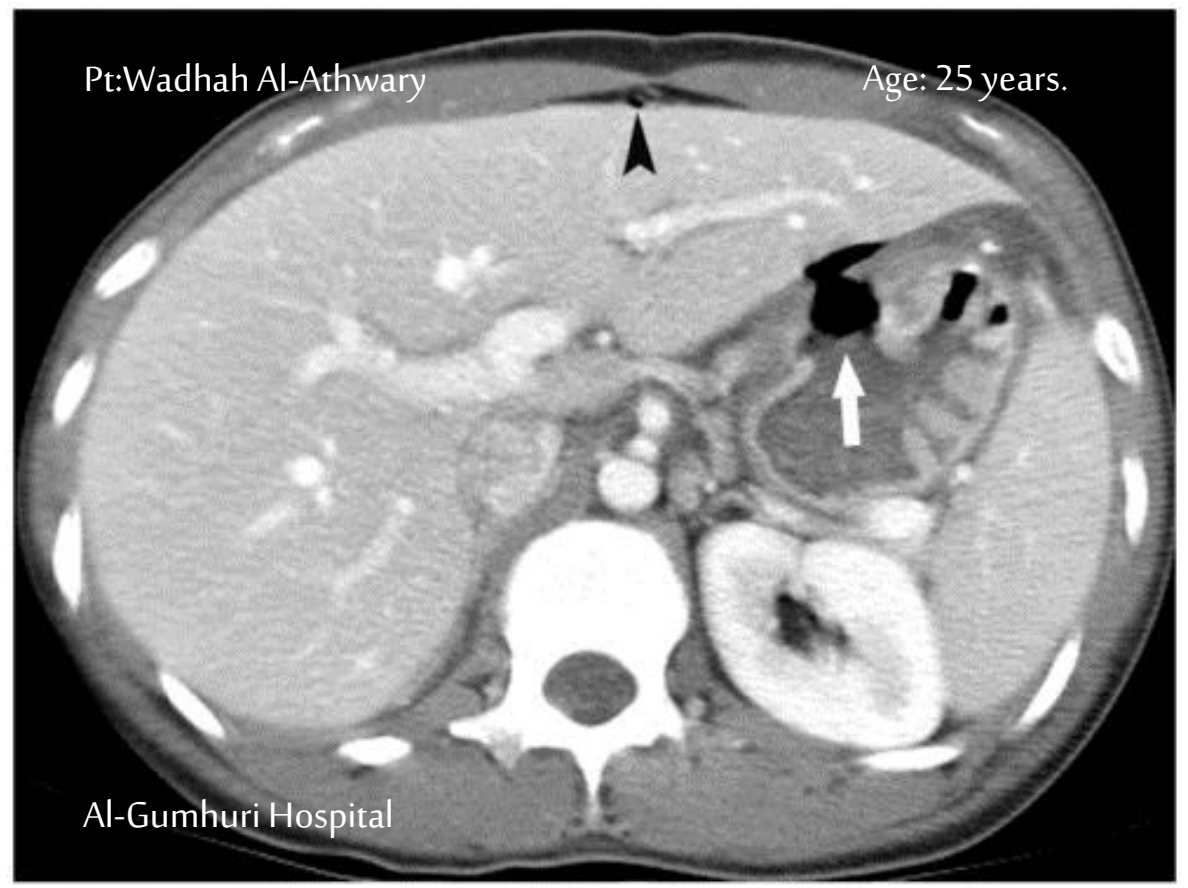

Figure (3) 


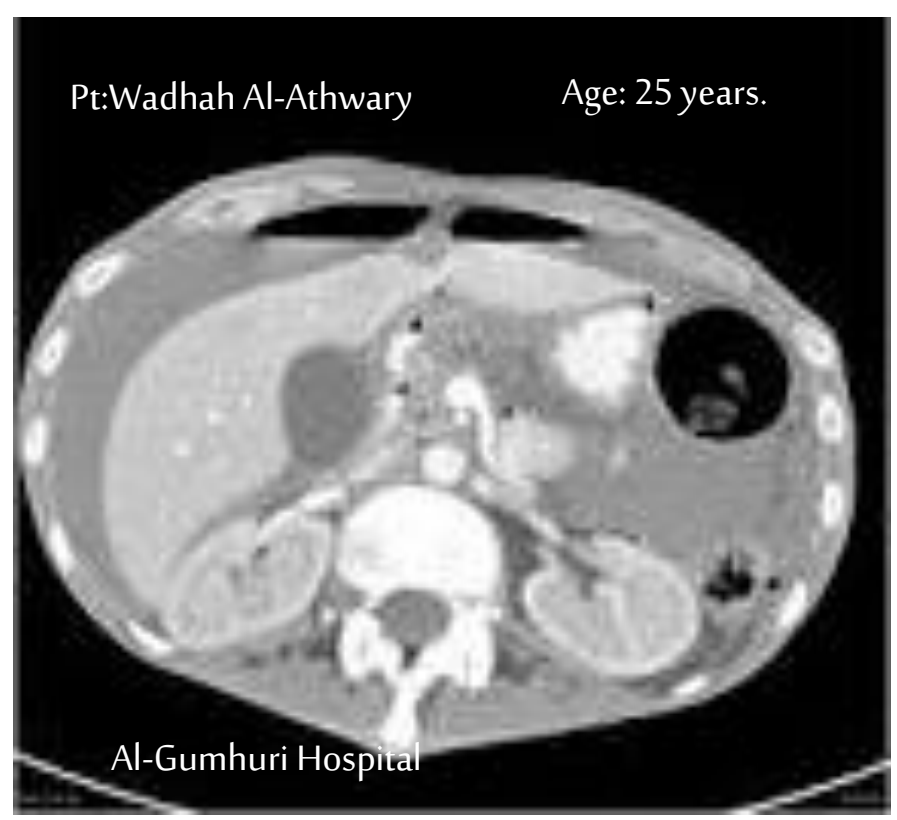

Figure (4)

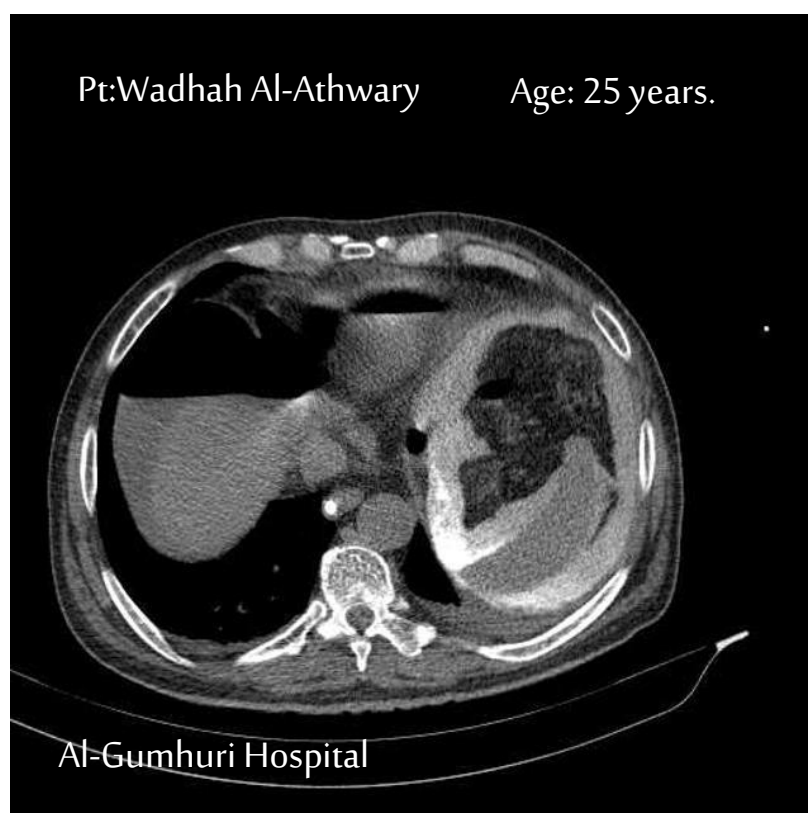

Figure (5)

\section{METHODS}

This is prospective observational study conducted on patients operated for PPU at algomhuri hospital, for 3years during 2017-2020. Preoperative, operative and postoperative records of these patients were collected. Patient's detailed history and through physical examination and investigation like complete blood count, blood grouping, serum creatinine and serum urea and random blood sugar, viral marker (HIV, $\mathrm{HBsAg}, \mathrm{HBcAg}$ ) and serum amylase were performed. Radiological investigations like $\mathrm{x}$-ray abdomen erect or chest were done in all patients who were suspected of peptic ulcer perforation.

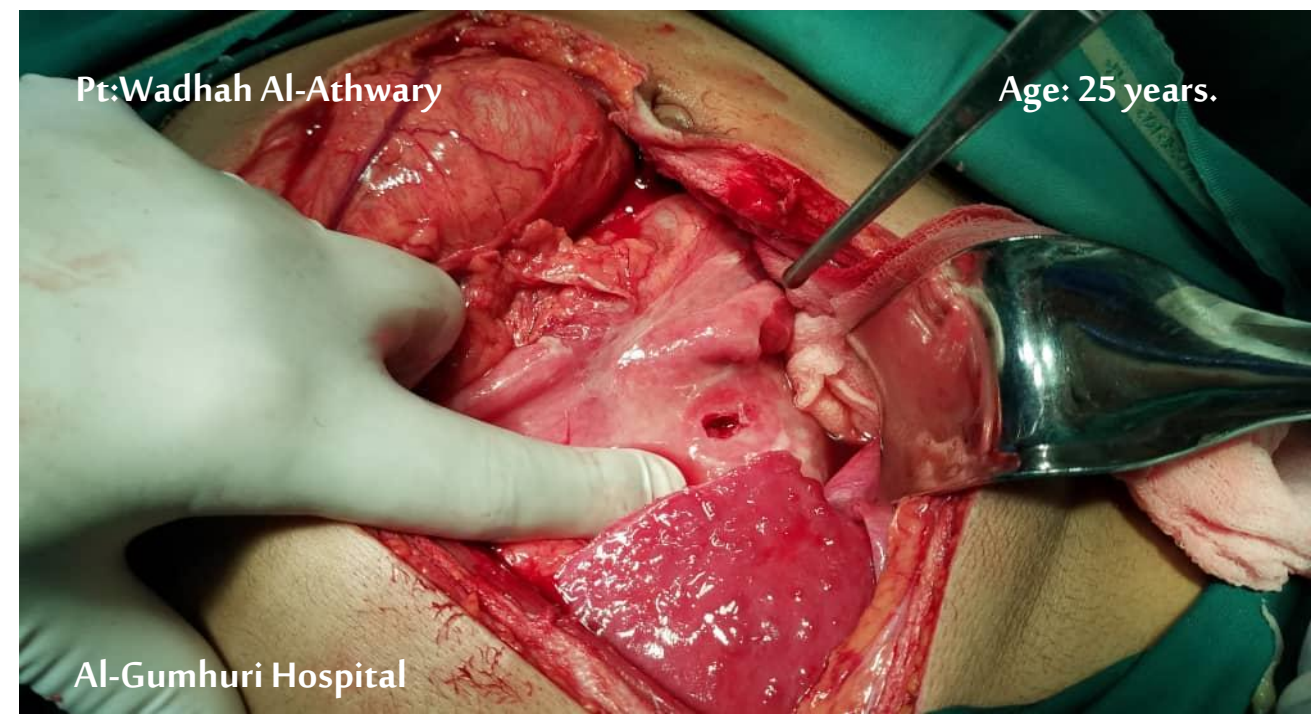

Figure (6) 
The diagnosis of PPU was made from history, plain x-ray abdomen or chest by presence of free gas under right dome of diaphragm and confirmed at laparotomy. Patients were put on NGT tube, intravenous fluid (crystalloid), intravenous antibiotics and antiulcer drugs. Adequate hydration was indicated by an hourly urine output of 30-50 ml. After adequate resuscitation laparotomy was performed through upper midline incision and perforation site identified. Simple closure of perforation with reinforcement of omental patch (Graham's technique) was done.
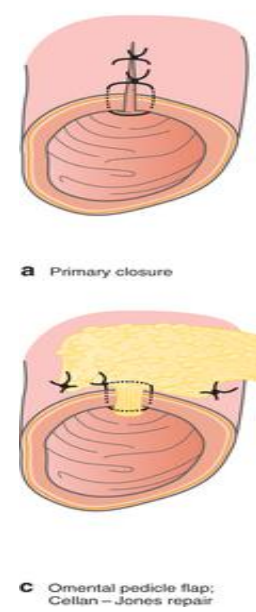

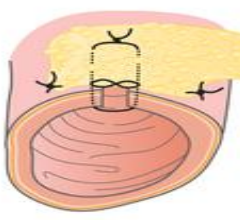

b Primary closure with
omentat poscicto napp

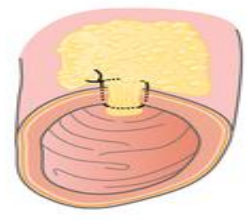

d Free amental plug:

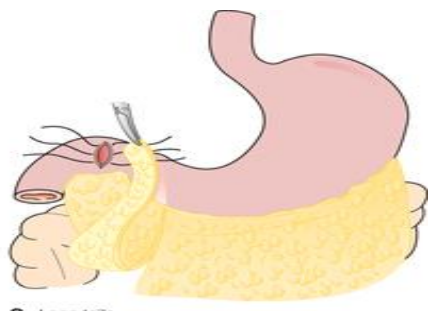

e Long tases

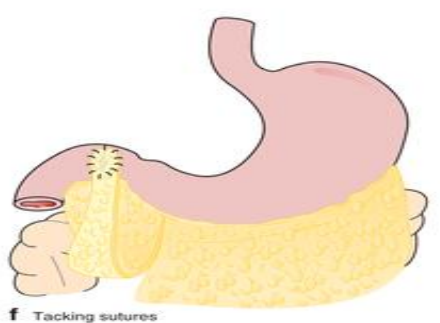

(20) Figure (7)

Silk or vicryl suture material was used for the repair. Thorough peritoneal lavage was performed. Placement of intraperitoneal drain was optional. We put prophylactic drain in all cases. Usually two drains one in pelvis and another in Morrison's pouch were put.

Postoperatively these patients were kept nil per orally up to 5th postoperative day along with antibiotics, PPI and intravenous fluid. Regular monitoring of blood pressure, pulse, respiration, saturation of oxygen by pulse oximetry and urine output were done. Oral clear water sips allowed after 5th postoperative day, followed by semi solid and solid diet were started gradually. Drains were taken out, once patient is thriving and drainage is clear and $<30 \mathrm{ml} /$ day. Dressing was done on third postoperative day and regularly thereafter. Data of these patients collected of format, tabulated and analyzed and following observation is obtained.

\section{RESULTS}

62 cases enrolled for the study, 2 case were female and the last were male. Male patients were predominant than female in a ratio of 60:2. 
Table 1 shows clinical presentation of the patients in which the common symptoms were abdominal pain, distension and vomiting whereas common signs were guarding and rigidity, rebound tenderness, , distension of abdomen and absent of bowel sound in decreasing order of frequency.

Table (1) Clinical presentation ( $n=62$ ).

\begin{tabular}{|c|c|}
\hline Symptoms & $\%$ \\
\hline Abdominal pain & 100 \\
\hline Distension & 80.6 \\
\hline Nausea & 24 \\
\hline Vomiting & 88.7 \\
\hline Signs & 100 \\
\hline Rebound tenderness & 100 \\
\hline Distension & 80.6 \\
\hline
\end{tabular}

Table 2 shows age wise distribution. Age ranges from 20 to $>60$ years and majority of the patients belongs to the age group 30-40 years

\section{Graph (1) Clinical presentation $(n=62)$}

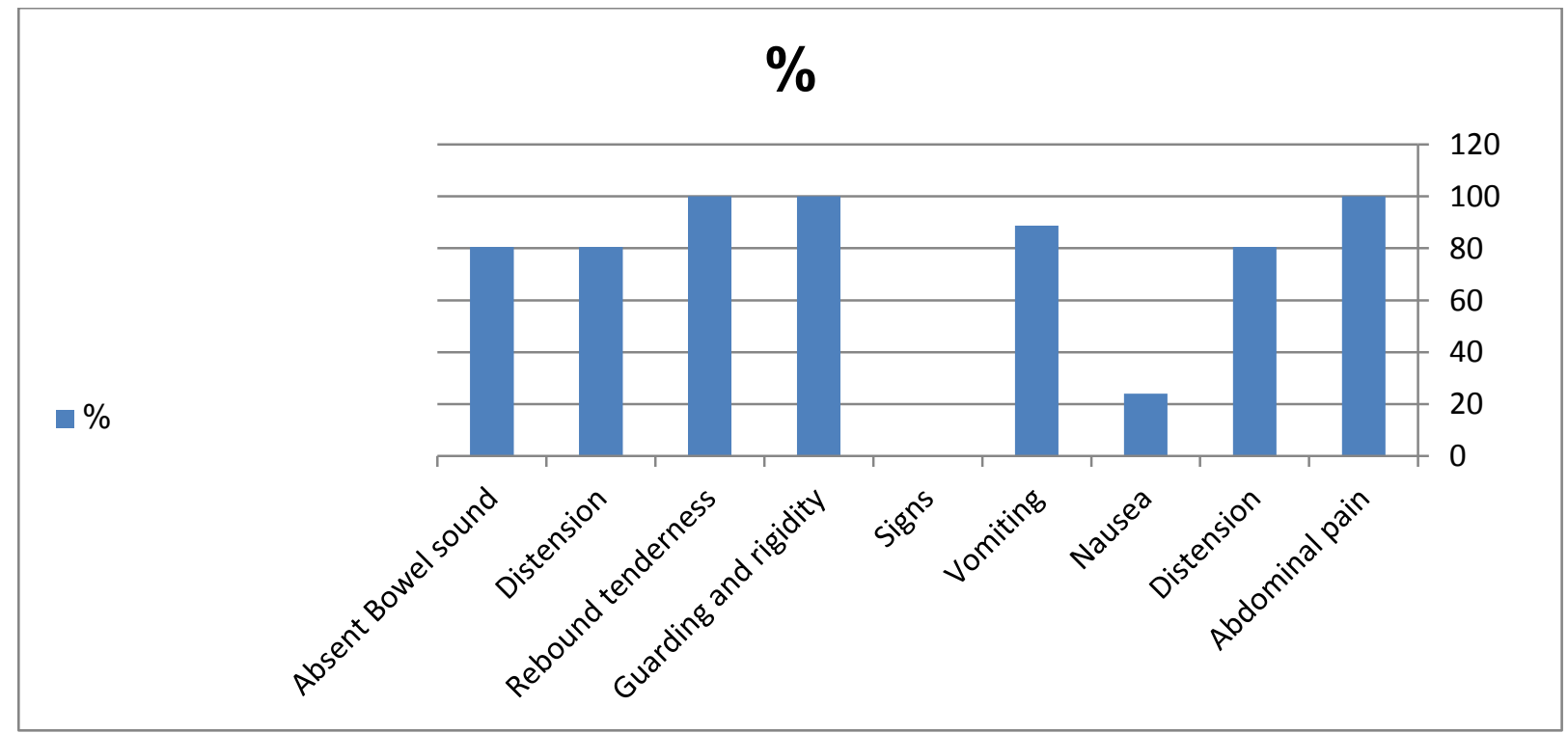

Table (2) Age wise distribution of cases $(n=62)$.

\begin{tabular}{|c|c|c|}
\hline Age (in years) & No. & $\%$ \\
\hline $20-30$ & 2 & 48.3 \\
\hline $30-40$ & 30 & 32.2 \\
\hline $40-50$ & 20 & 9.6 \\
\hline $50-60$ & 6 & 9.3 \\
\hline
\end{tabular}


المجلة العربية للعلوم ونشر الأبحاث ـ مجلة العلوم الطبية والصيدلاتية ـ المجلد الخامس ـ العدد الثاني ـ يونيو 2021 م

\begin{tabular}{|c|c|c|}
\hline Age (in years) & No. & $\%$ \\
\hline$>60$ & 4 & 6.4 \\
\hline Total & 62 & 100 \\
\hline
\end{tabular}

Graph (2) Age wise distribution of cases ( $n=62$ )

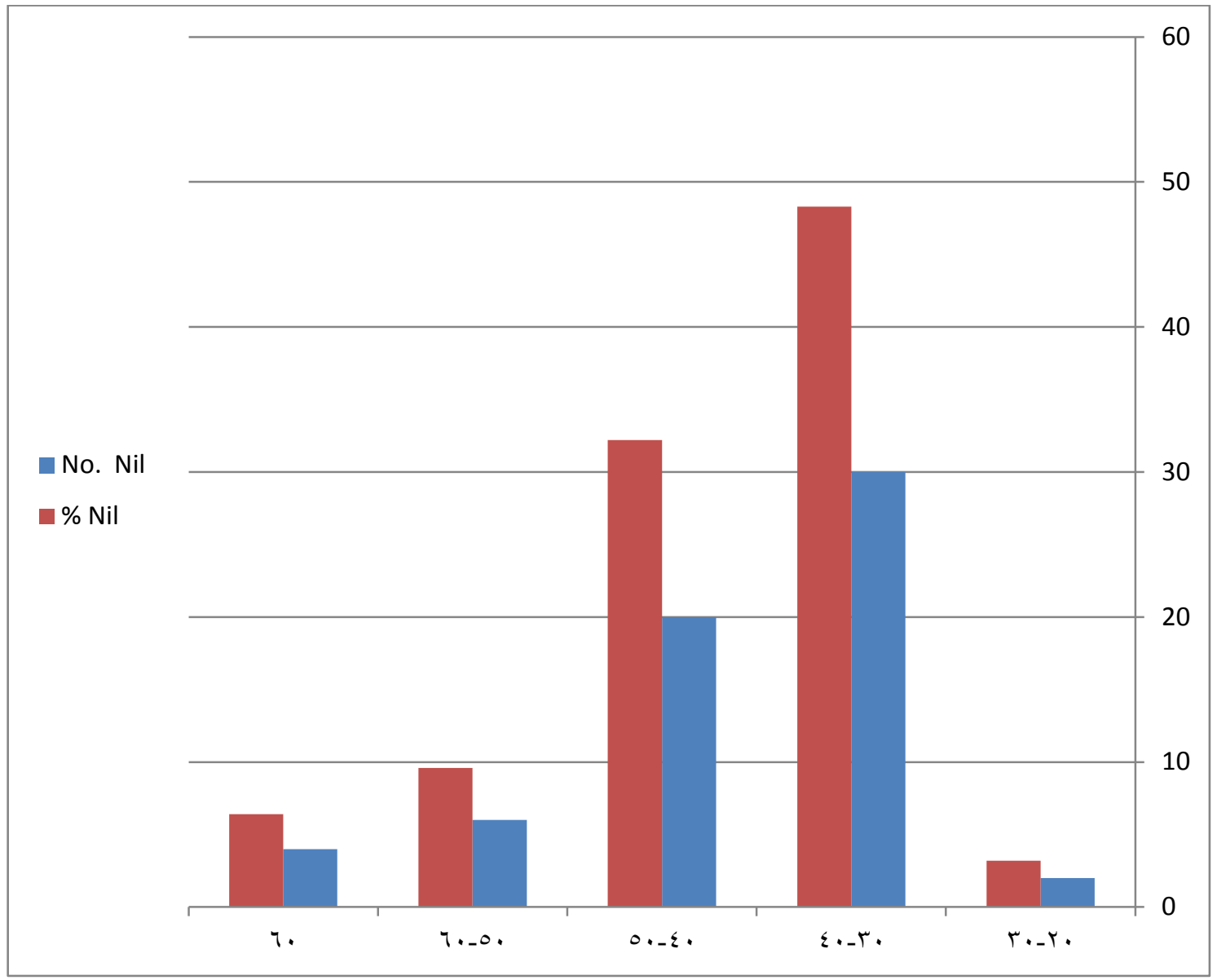

Table (3) Site and size of perforation ( $n=62)$.

\begin{tabular}{|c|c|c|c|c|}
\hline \multirow{2}{*}{ Site of perforation } & \multicolumn{2}{|c|}{ Size of perforation } & \multicolumn{2}{|c|}{ No. of patient } \\
\hline & $\leq 5 \mathrm{~mm}$ & $>5 \mathrm{~mm}$ & No. & $\%$ \\
\hline Duodenal and pre-pyloric & 40 & 15 & 55 & 88.7 \\
\hline Gastric & 5 & 2 & 7 & 11.3 \\
\hline
\end{tabular}

Table 3 shows distribution of cases according to site and size of peptic ulcer perforation. Majority (88.7\%) perforations were from duodenal and pre-pyloric group and majority of the perforations were equal or less than $5 \mathrm{~mm}$ in size.

Table (4) Free gas under diaphragm

\begin{tabular}{|c|c|c|}
\hline Free gas & No. of Case & $\%$ \\
\hline Right side & 57 & 91.9 \\
\hline Left side & 3 & 4.8 \\
\hline
\end{tabular}


المجلة العربية للعلوم ونشر الأبحاث ـ مجلة العلوم الطبية والصيدلانية ـ المجلد الخامس ـ العدد الثاني ـ يونيو 2021 م

\begin{tabular}{|c|c|c|}
\hline Free gas & No. of Case & $\%$ \\
\hline Absent & 2 & 3.22 \\
\hline Total & 62 & 100 \\
\hline
\end{tabular}

Graph (4) Free gas under diaphragm

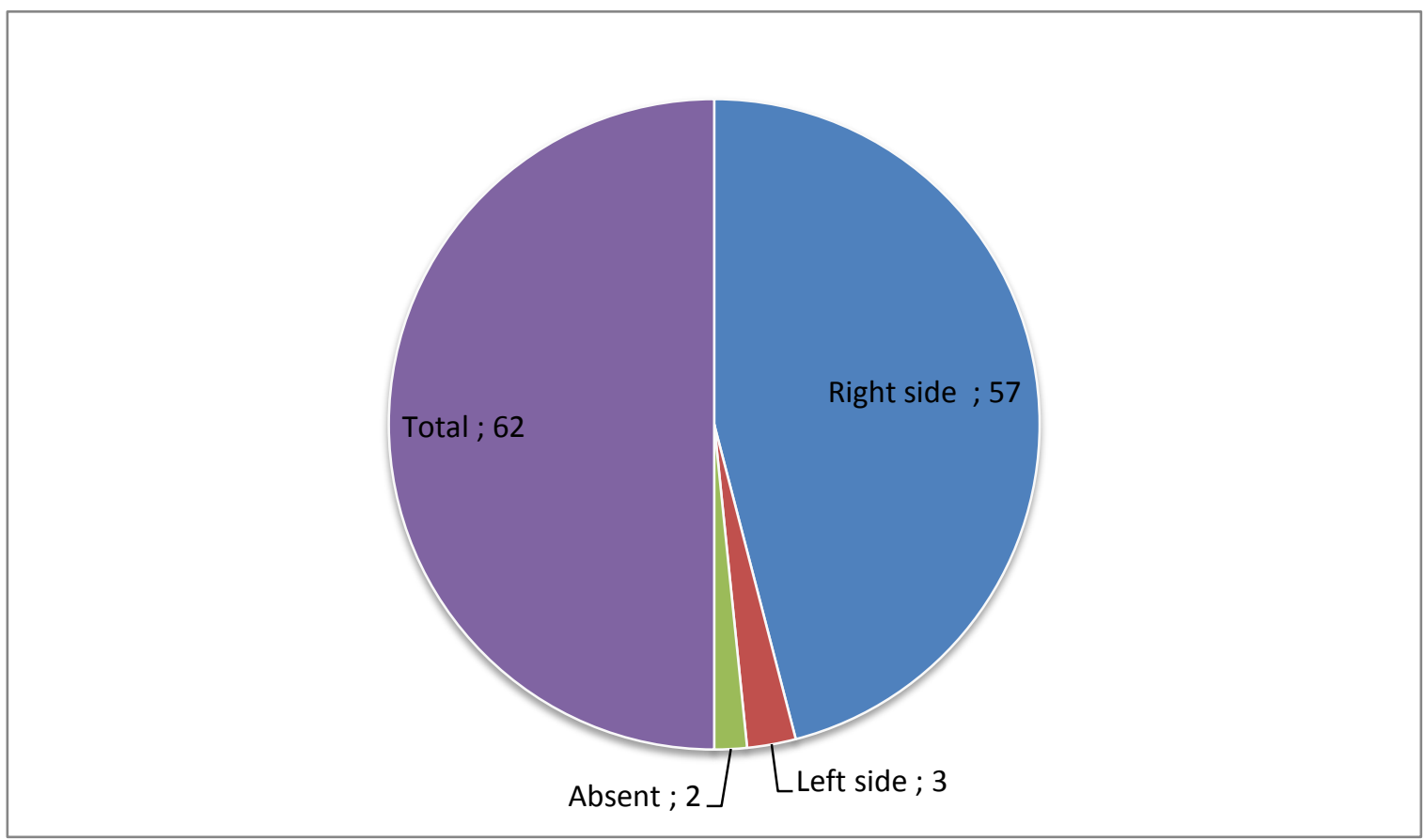

Table 4 shows distribution of cases according to the free gas under diaphragm. Majority (92\%) of the cases had free gas under right dome of diaphragm while in minority of cases it was absent.

Table (5) Duration onset of symptom ( $n=62)$.

\begin{tabular}{|c|c|c|}
\hline Duration (in hours) & \multicolumn{2}{|c|}{ No. of cases } \\
\hline $0-12$ & 4 & 6.45 \\
\hline $12-24$ & 6 & 9.67 \\
\hline $24-48$ & 10 & 16.12 \\
\hline $48-72$ & 12 & 19.3 \\
\hline$>72$ & 30 & 48.38 \\
\hline Total & 62 & 100 \\
\hline
\end{tabular}


المجلة العربية للعلوم ونشر الأبحاث ـ مجلة العلوم الطبية والصيدلاتية ـ المجلد الخامس ـ العدد الثاني ـ يونيو 2021 م

Graph (5) Duration onset of symptom ( $n=62)$.

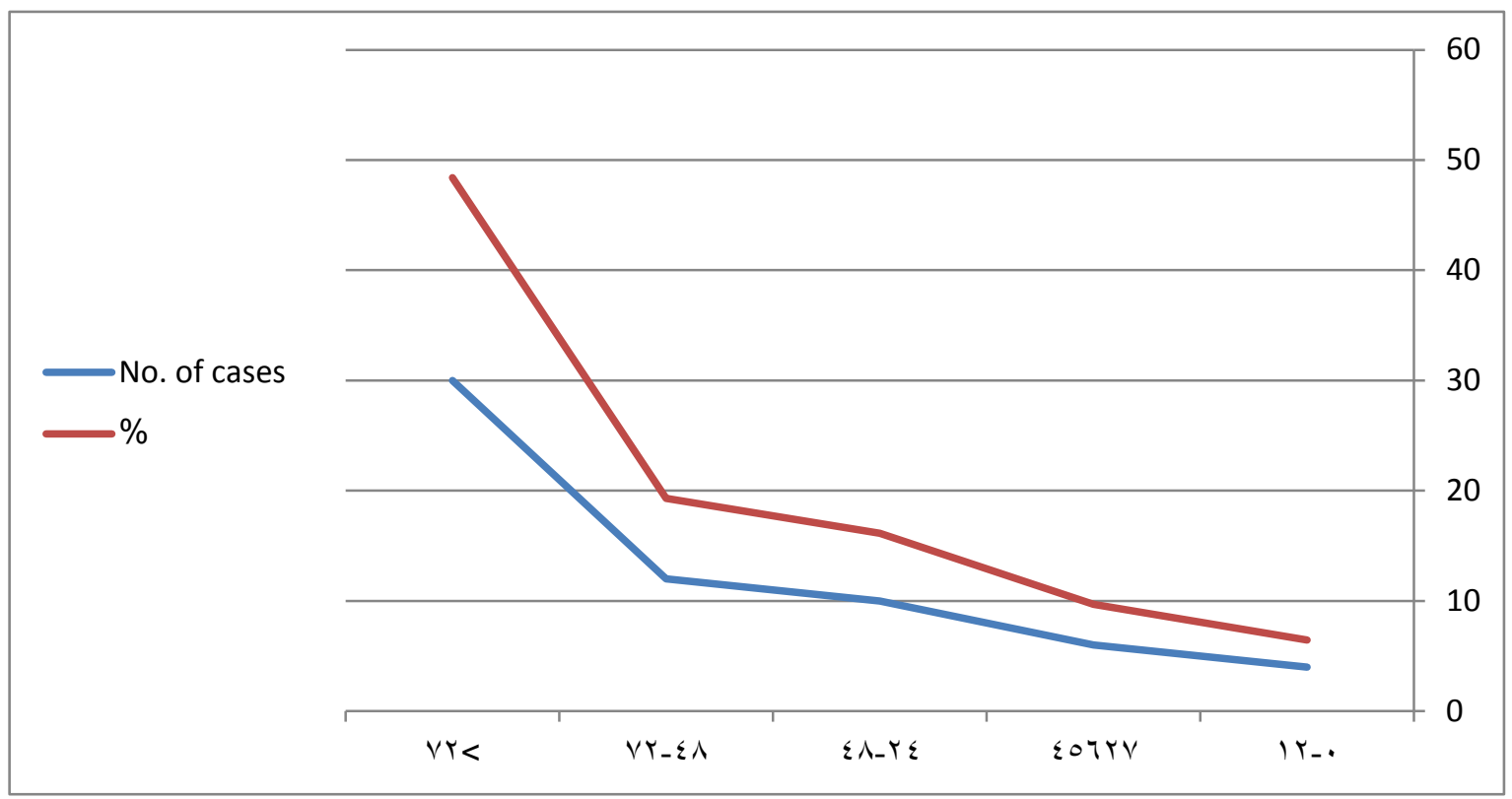

Table (6) Treatment ( $n=62)$.

\begin{tabular}{|c|c|c|}
\hline Procedure & No. of patients & $\%$ \\
\hline Graham's repair & 60 & 96.77 \\
\hline Graham's repair with GJ & 2 & 3.23 \\
\hline \multicolumn{3}{|l|}{ Prophylactic peritoneal drainage } \\
\hline Yes & 62 & 100 \\
\hline
\end{tabular}

Table (7) Post-operative complications (20\%).

\begin{tabular}{|c|c|c|}
\hline Types of complications & No. of cases & $\%$ \\
\hline Wound infection & 10 & 16.1 \\
\hline Wound dehiscence & 06 & 9.67 \\
\hline Postoperative pyrexia & 12 & 19.35 \\
\hline Diarrhea & 2 & 3.22 \\
\hline Duodenal/gastric fistula & 04 & 6.4 \\
\hline Pelvic abscess & 04 & 6.4 \\
\hline Pneumonia & 07 & 11.29 \\
\hline Death & 02 & 3.22 \\
\hline
\end{tabular}

Table 7 shows complication. The post-operative complications in decreasing order of frequency were postoperative pyrexia (19.35\%), wound infection (16.1\%), pneumonia (11.29\%). two patients (3.2\%) died in postoperative period. The morbidity and mortality rates were $20 \%$ and (3.2\%) respectively 


\section{Graph (7) Post-operative complications (20\%)}

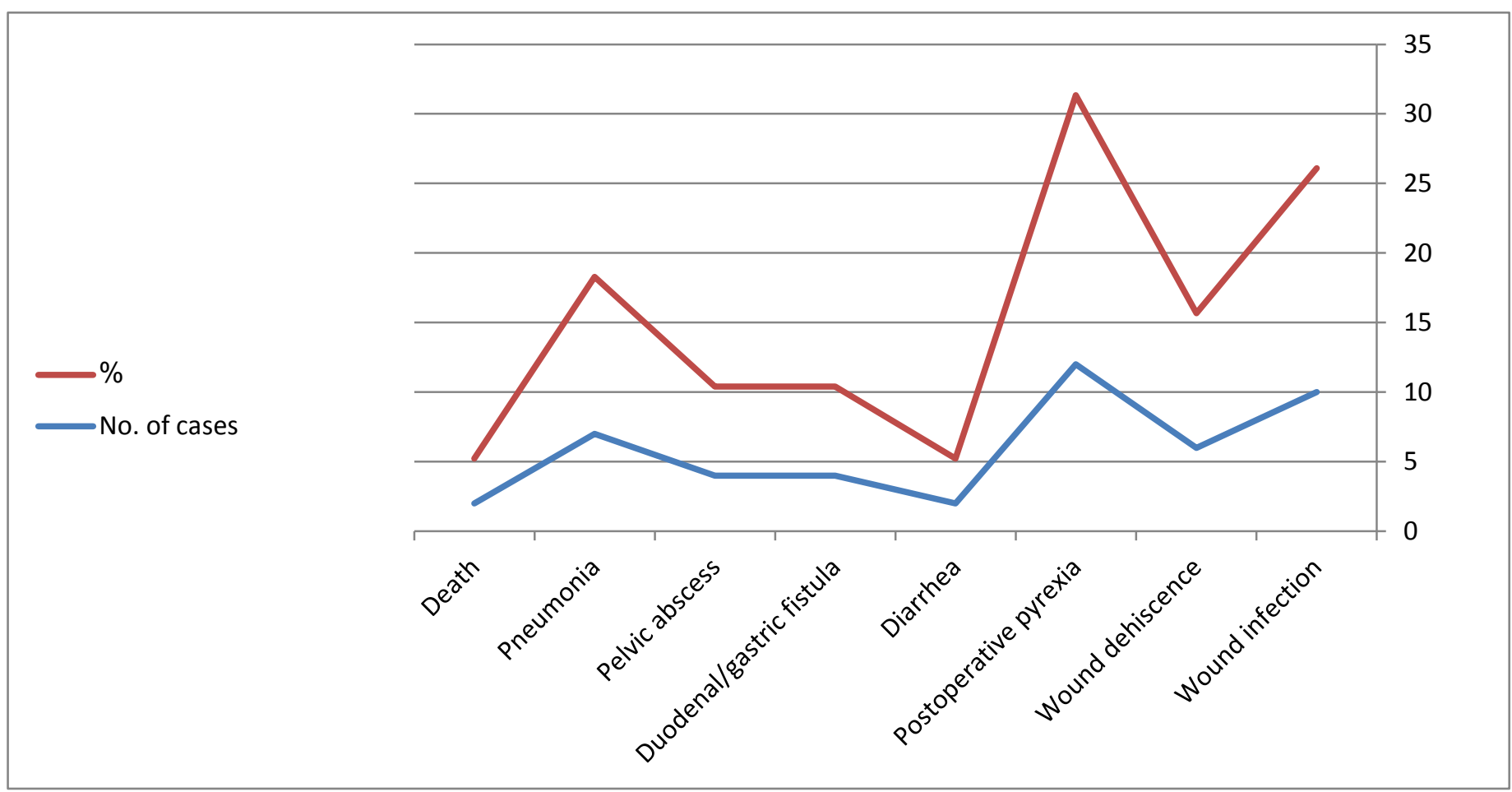

\section{DISCUSSION}

In this review, a total of 62 patients were enrolled over a three year period giving an average of 20 cases annually

The rate of H.pylori infection in patients with perforated peptic ulcers ranges from $50-80 \%$ and H.pylori infection as a risk factor for perforated peptic ulcer disease, appear to be more relevant in younger patients. This is in contrast to elderly patients, where NSAID may play a more significant etiological role. Use of NSAID is an important cause of perforated peptic ulcer in the west.in our series, NSAID use as an offending cause could be attributable in only $10.7 \%$ patients, NSAID inhibit prostaglandin synthesis so further reducing gastric mucosal blood flow. In the present study, perforated peptic ulcer disease were found to be most common in the fourth decade of life and tend to affect more males than females which is comparable with other studies in developing countries. ${ }^{(23)}$ An $x$-ray abdomen or thorax in standing position will reveal gas under diaphragm in about $80-85 \%$ of cases. ${ }^{(26,27)}$ Some centers also prefer ultrasonography and CT scan with oral contrast. With current radiological technique $80-90 \%$ of cases are correctly diagnosed.

${ }^{(28)}$ We diagnosed all the cases with the help of clinical symptoms and physical examination and plain $\mathrm{x}$-ray abdomen or chest in erect position. In this series $96.78 \%$ cases had free gas under diaphragm (Table 4). Little of the patient required CT scan in this series. 
Treatment begins with diagnosis of acute abdomen. It consists of fluid resuscitation, nasogastric suction, $\mathrm{H} 2$ blocker or proton pump inhibitor and broad spectrum antibiotics. Once PPU has been confirmed then different therapeutic option are explored. ${ }^{(28)}$ Decision regarding operative and conservative therapy is to be taken according to the condition of patient and by experienced member of the team. If surgery is to be planned, then decision of the type of procedure should be done. Whether a simple closure with or without omentoplasty will be sufficient.

${ }^{(29)}$ The role of definitive surgery was based on "no acid, no ulcer" and most of the ulcers were thought to be consequence of excessive acid secretion caused by smoking, alcohol use, stress or other environmental factors and further supported by the study which revealed ulcer recurrence following simple closure ranges from $30-70 \% .{ }^{(30,31)}$ Definitive surgery along with closure of perforation in the same sitting prolongs the duration of surgery and increase mortality (1 vs 3.3-13.4\%). ${ }^{(31-33)}$ Therefore; there is progressive decline in the role of definitive surgery due to decrease recurrence rate of ulcer due to life style modification and availability of potent acid reducing agents like $\mathrm{H} 2$ blockers and PPIs. There is further decline of definitive ulcer surgery after discovery of $\mathrm{H}$. pylori as the causative agent which can be treated by drugs. Presently the role of definitive surgery is limited only for patients with ulcer perforation with negative $\mathrm{H}$. pylori, recurrent ulcer despite triple therapy or perforation during triple therapy course. ${ }^{(28,34,}$ ${ }^{35,36)}$ In the present series we managed almost cases with Graham's omentopexy and only two cases we done Graham omentopexy with G). Similar to the recommendation of previous workers, we subject patient to endoscopy if symptom persists and does not improve after acid reducing drugs. These cases were managed as per endoscopic finding.

${ }^{(30)}$ Non-operative management is based on Taylor observation which consists of nasogastric suction, antibiotics, intravenous fluid and now days $\mathrm{H}$. pylori triple therapy. ${ }^{(33,34)}$ It was based on Crisp observation during laparotomy. He noticed that abdominal cavity was filled with adhesions to the surrounding viscera which prevented the leakage from the stomach in peritoneum. It is general consensus that conservative treatment can be considered in cases with associated morbidity to surgery, anesthesia, old age $>70$ years, time gap between perforation and start of treatment is $<12$ hours and documented contrast study that perforation has sealed. There is conflicting reports about advantages and disadvantages in conservative treatment. Some are in favour and others are not in favour. Those who are in favour argue that operation, anesthesia in associated morbidity, reduction in postoperative intraabdominal adhesion induced by surgery which makes future elective definitive surgery for PUD or other indications difficult but hospital stay is shorter where as those who are not in favour, argue that there is prolonged hospital stay, higher mortality rate if conservative fails, lack of benefit of laparoscopy as diagnostic tool in cases of patient with misdiagnosis and missing of gastric cancer. ${ }^{(35,37,38)}$ So in cases in whom conservative treatment is chosen UGI endoscopy should be performed to rule out gastric cancer. In the present series we have not managed any case conservatively. 
Operative management consists of upper midline incision followed by identification of perforation and closure as advice by Graham using three stiches enforcing with omentum. If ulcer is gastric, biopsy should be done to exclude gastric cancer. Proper sealing can be confirmed by putting dye via NGT. This follows peritoneal toilet and putting peritoneal drainage which is controversial. ${ }^{(39,40)}$ Some surgeons infiltrate abdominal wound Bupivacaine $0.25 \%$ at the end of procedure. Various methods have been advocated for repair of perforation. These are Cellan-Jones method and Graham's omental patch technique. ${ }^{(41,42)}$ Today's Graham's technique is misnomer, in original technique Graham has used free graft of omentum, putting 3 sutures with a piece of free omentum laid over these sutures and then tied. No attempt was usually made primary close the hole. The omental graft produces stimulus for fibrous formation. This approach is gold standard since its publication. Very often surgeon mention they used Graham's omental patch, but they actually used pedicle omental graft. Schein have advocated the plugging of perforation with omentum. ${ }^{(23)}$ We used omental pedicled graft along with three stiches to close the perforation. Biopsy was taken in every case of gastric ulcer perforation. We have found one case in which malignancy was diagnosed. Ulcer healed with usual treatment. Postoperative irrigation is done in all cases. Irrigation with warm saline up to 6 liter is recommended.We do prophylactic drainage of peritoneal cavity after closure perforation. It has been reported that drain does not reduces the incidence of intra-abdominal fluid collection or abscess formation. ${ }^{(43)}$ On the other hand, drain site can become infected $(10 \%)$ and can cause intestinal obstruction. ${ }^{(43,45)}$ It is argued in favour that drain signal early leak. But clinically it has been seen that drains are blocked early by fibrinous exudates and plugged by omentum and whenever leak happens fluid does not come out from drain but it comes out from the incision site. In one of the study it has been observed that drains are not beneficial. It has been reported that well equipped centre radiological investigation like USG or CT scan and good clinical observation by experienced surgeon can provide all information probably better than a nonproductive drain.

${ }^{(30,31)}$ During 1980's and before definitive surgery was strongly advocated to prevent recurrence which was reported up to $70 \%$.Some surgeon performs definitive surgery during closure of perforation. But it was reported that adding definitive surgery prolongs the surgical time and this adds the mortality and morbidity to already sick patient.

It can be done on elective basis after the recovery of first surgery. Slowly and slowly both trend has declined because surgeons were not willing to do definitive surgery along with closure of perforation as patient is too sick and secondly these patients usually lost during follow up and those who return for follow up and are asymptomatic. If patient on follow up is symptomatic, a UGI endoscopy is usually advised. If endoscopy shows a good healed ulcer, regular follow up with acid reducing drug is advised. If endoscopy shows recurrence of ulcer or symptom persists even after treatment, acid reducing surgery is advised. Presently definitive ulcer surgery is advised in PPU with negative H. pylori, recurrent ulcer despite of triple drug therapy or those cases who develop PPU despite of on ripple drug therapy. ${ }^{(25,34,36)}$ In these 
patients parietal cell vagotomy is recommended if needed combined with anterior linear gastrectomy.

(46) This procedure can now be performed safely laparoscopically. ${ }^{(34,47)}$ In the present study 2 cases were diagnosed as recurrent ulcer. These cases were subjected to elective truncal vagotomy and gastrojejunostomy. Postoperatively these cases were managed with nasogastric aspiration, intravenous fluid and antibiotics, painkiller and vital monitoring. Duration of nasogastric aspiration is controversial. Some expert advice for 48 hours only while other use for 3 days. ${ }^{(45,48)}$ We used nasogastric aspiration for average 5 days. Another differing opinion exists regarding starting of oral feed. Some advocate early start of oral feed while others use it after 5 days postoperatively when gastric aspirate reduced and abdominal distension settled and patient is passing flatus and faeces. General trend of empiric use of post-operative antibiotics consisting three drug protocol covering gram positive and negative and anti-anaerobe was usual. Most antibiotic protocols have aminoglycosides. ${ }^{(49)}$ But recent study has shown that there is no role of aminoglycoside along with 3rd generation cephalosporin antibiotics. ${ }^{(50)}$ We have also found in this series that non aminoglycoside based 2 antibiotic drug consisting of 3rd generation cephalosporin and metronidazole or tinidazole is equally effective.

Postoperative complication includes pneumonia, wound infection, UTI, suture leak, abscess formation, heart problem, ileus, fistula, wound dehiscence, sepsis, reoperation and death. Over all complication rate ranges from $15-38 \%$ in previous published reports. $(34,43,51)$ Incidence of the complications $(20 \%)$ in the present study is comparable to the previous reports. The most commonly observed postoperative complication was post-operative pyrexia followed by wound infection (Table 7).

The overall mortality rates in the present study was 2 case (3.2\%) (Table 7) which is less than the previous published reports $(6-10 \%) .{ }^{(51,52)}$ This mortality reaches to $30-35 \%$ of patients with PPU who have sepsis on arrival at the operation theatre and sepsis is believed to be the cause of fatalities in $30-40 \%$ of cases. Increase in mortality rate is reported to be associated with age $>60$ years, delay in treatment for $>24$ hours, shock at admission (systolic blood pressure $<100 \mathrm{mmHg}$ and concomitant disease. ${ }^{(34)}$ Gastric ulcer perforation is associated with 3 -5-fold increase in mortality. ${ }^{(34,47)}$ It has been observed during the study that those cases operated without optimizing hemodynamic balance, show increase morbidity and mortality. So the old concept of "no sun set and sun rise" the patient should be operated should be discouraged. In the present series morality rates are less and this may be because of majority of our patients are young and operations were done after achieving good hemodynamic status.

\section{CONCLUSION}

Adequate fluid resuscitation to achieve optimal hemodynamic status and optimal kidney function is the key to decrease morbidity and mortality rates. Simple closure with omental patch followed by Helicobacter pylori eradication is effective with excellent outcome in most of survivor despite of late 
presentation. Definitive surgery for ulcer recurrence is no more done except in negative H.pylori, recurrent ulcer despite of triple drug therapy or those cases who develop PPU despite of on triple drug therapy.

Gastric ulcer perforation is associated with 3-5 fold increase in mortality, biopsy was taken in every case of gastric ulcer perforation.

The most commonly observed complication was post-operative pyrexia followed by wound infection.

In cases in whom conservative treatment is chosen UGI endoscopy should be perforated to rule out gastric cancer.

\section{RECOMMENDATION}

We Recommend prompt evaluation and early recognition of the patient with perforated peptic ulcer associated sepsis to prevent further organ failure and to reduce mortality.

Exploratory laparotomy and mental patch repair remains the gold standard and laparoscopic surgery should be considered when expertise surgery is available.

Gastrectomy is recommended in patients with large or malignant ulcer to enhance outcomes; however the outcomes of patients treated with gastric resection remain inferior.

The recommended surgical approach (laparoscopic versus open) for perforated peptic ulcer as follow:

- stable patients: laparoscopic approach, unless equipment and skilled person are not available, in which case an open approach is recommended.

- unstable patients: open surgery.

In case suspected perforated peptic ulcer if free air is not seen on imaging and perforation remains a concern, imaging with water-soluble contrast (oral or via nasogastric tube) is recommended.

The recommended antimicrobial regimen and duration of therapy in perforated peptic ulcer are initiation of empiric broad-spectrum antibiotics as soon as possible, targeting gram negative, gram positive and anaerobic bacteria.

\section{References}

1- Testini M, Portincasa P, Piccinni G, Lissidini G, Pellegni F, Greco L. Significant factors associated with fatal outcome in emergency open surgery for perforated peptic ulcer. WJ Gastroenterol.2003;9:233840.

2- Feldman M, Friedman L, Brandt L. Peptic ulcer and its complications. In: Scharschmidt BF, SleingerMH. Sleisinger and Fordtran's gastrointestinal and liver disease: pathophysiology, diagnosis, management. 6th ed. Philadelphia: W. B. Saunders;1998: 620-678. 
3- Rajesh V, Sarathchandra S, Smile SR. Risk factors predicting operative mortality in perforated pepticulcer disease. Trop Gastroenterol. 2003;24:148-50.

4- Hermansson M, Holstein CS, Ziling T. Surgical approach and prognostic factors after peptic ulcerperforation. Eur J Surg.1999;165:556-72.

5- Boey J, Choi KY, Alagarantnam TT, Poon A. Risk stratification in perforated duodenal ulcer: a prospective validation of predictive factors. Ann Surg. 1986;205:22-6.Khan S et al. Int Surg J. 2019 Oct;6(10):3643-3649 International Surgery Journal | October 2019| Vol 6 | Issue 10 Page 3648.

6- Elnagib E, Mahdi SE, Mohamed E, Ahmed ME. Perforated peptic ulcer in Khartoum. Khartoum Med J. $2008 ; 1(2) ; 62-4$.

7- Gutierrez L, Pena C, Merquez R, Fakih F, Adame E, Medina J. Simple closure or vagotomy andpyloroplasty for the treatment of a perforated duodenal ulcer comparison of results. Dig Surg. 2000;17:225.

8- [Guideline] Chey WD, Wong BC. American College of Gastroenterology guideline on the management of Helicobacter pylori infection. Am J Gastroenterol. 2007 Aug. 102(8):1808-25. [Medline].

9- Javid G, Zargar SA, U-Saif R, et al. Comparison of p.o. or i.v. proton pump inhibitors on 72-h intragastric pH in bleeding peptic ulcer. J Gastroenterol Hepatol. 2009 Jul. 24(7):1236-43. [Medline].

10- Lai KC, Lam SK, Chu KM, et al. Lansoprazole for the prevention of recurrences of ulcer complications from long-term low-dose aspirin use. N Engl J Med. 2002 Jun 27. 346(26):2033-8. [Medline].

11- Lai KC, Lam SK, Chu KM, et al. Lansoprazole reduces ulcer relapse after eradication of Helicobacter pylori in nonsteroidal anti-inflammatory drug users--a randomized trial. Aliment Pharmacol Ther. 2003 Oct 15. 18(8):829-36. [Medline].

12- Laine L, Curtis SP, Cryer B, Kaur A, Cannon CP. Risk factors for NSAID-associated upper Gl clinical events in a long-term prospective study of 34701 arthritis patients. Aliment Pharmacol Ther. 2010 Nov. 32(10):1240-8. [Medline]. Sung J), Tsoi KK, Ma TK, Yung MY, Lau JY, Chiu PW. Causes of mortality in patients with peptic ulcer bleeding: a prospective cohort study of 10, 428 cases. Am J Gastroenterol. 2010 Jan. 105(1):84-9. [Medline].

13- Khodadoostan M, Karami-Horestani M, Shavakhi A, Sebghatollahi V. Endoscopic treatment for highrisk bleeding peptic ulcers: A randomized, controlled trial of epinephrine alone with epinephrine plus fresh frozen plasma. J Res Med Sci. 2016. 21:135. [Medline].

14- Leontiadis Gl, Sreedharan A, Dorward S, et al. Systematic reviews of the clinical effectiveness and costeffectiveness of proton pump inhibitors in acute upper gastrointestinal bleeding. Health Technol Assess. 2007 Dec. 11(51):iii-iv, 1-164. [Medline].

15- Larssen L, Moger T, Bjornbeth BA, Lygren I, Klow NE. Transcatheter arterial embolization in the management of bleeding duodenal ulcers: a 5.5-year retrospective study of treatment and outcome. Scand J Gastroenterol. 2008. 43(2):217-22. [Medline]. 
16- Travis AC, Wasan SK, Saltzman JR. Model to predict rebleeding following endoscopic therapy for nonvariceal upper gastrointestinal hemorrhage.J Gastroenterol Hepatol. 2008 Oct. 23(10):150510. [Medline].

17- Elmunzer BJ, Young SD, Inadomi JM, Schoenfeld P, Laine L. Systematic review of the predictors of recurrent hemorrhage after endoscopic hemostatic therapy for bleeding peptic ulcers. Am J Gastroenterol. 2008 Oct. 103(10):2625-32; quiz 2633. [Medline].

18- Chiu PW, Ng EK, Cheung FK, et al. Predicting mortality in patients with bleeding peptic ulcers after therapeutic endoscopy. Clin Gastroenterol Hepatol. 2009 Mar. 7(3):311-6; quiz 253. [Medline].

19- Kikkawa A, Iwakiri R, Ootani H, et al. Prevention of the rehaemorrhage of bleeding peptic ulcers: effects of Helicobacter pylori eradication and acid suppression. Aliment Pharmacol Ther. 2005 Jun. 21 Suppl 2:79-84. [Medline].

20- British Journal of Surgery.

21- Baron JH. Peptic ulcer. Mount Sinai J Med.2000;67:58-62.

22- Baron JH, Snnenberg A. Publication on peptic ulcer in Britain, France, Germany and The US. Eur J Gastroenterol Hepatol. 2002;14:711-5.

23- Schein M. Perforated peptic ulcer. In: Klipfel A, Fahoum BH, Gecelter G, Goreck P, Hirshberg A, Nystrom PO, et al, eds. Schein's common sense emergency abdominal surgery. Part III. Berlin: Springer-Verlag Berlin Heidelberg GmbH; 2005: 143-150.

24- Rayner HH. Treatment of perforated peptic ulcer. Lancet. 1930;2:107-8.

25- Sangter AH. Perforated peptic ulcer: an analysis of 100 consecutive cases. Lancet. 1939;23:1311-3.

26- Birk PM. Perforated peptic ulcer treated without operation. Lancet. 1947;4:467-8.

27- Lu WY, Leow CK.History of perforated duodenal and gastric ulcer. World J Surg.1997;21:890-6

28- Lagoo S, McMahon RL, Kakihra M, Pappas TN, Eubanks S. The sixth decision regarding perforated duodenal ulcer. JSLS. 2002;6:359-68.

29- Fujii Y, Asato M, Taniguchi N, Shigeta k, Omoto K, Itoh K, et al. Sonographic diagnosis and successful non-operative management of sealed perforated duodenal ulcer. J Clin Ultrasound. 2003:31:55-8.

30- Mishra SP, Prusti PN, Mishra BP. Surgical management of acute perforated duodenal ulcer. IJS. 1982;705-10.

31- Rains AJH, Capper WM, Knights, Cleland WP, Freeman MAR. Baily and Love's short practice of surgery. 15th ed. London: HK Lewis and company; 1971: 770.

32- Trolley JA. Definitive surgical therapy for perforated peptic ulcer. A review of 52 consecutive cases. Am J Surg. 1967;113:327-34.

33- DeBaky ME. Acute perforated gastroduodenal ulcer: a statistical analysis and review of literature. Surg. 1994;8:852-84.

34- Zittel TT, Jehle EC, Becker HD. Surgical management of peptic ulcer disease today: 
indication, technique and outcome. Lagenbecks Arch Surg. 2008;385:84-96.

35- Dovonan AJ, Berne TV, Dunovon JA. Perforated duodenal ulcer: an alternative therapeutic plan. Arch Surg. 1998;133:1166-71.

36- Schwesinger WH, Page CP, Srinek KR, Gaskill H, Melnick G, Strodel WE. Operation for peptic ulcer disease: paradigm lost. J Gastrointest Surg. 2001;5:438-43.

37- Bucher P, Oulhaci W, Morel P, Ris F, Huber O. Results of conservative treatment for perforated gastroduodenal ulcer in patients not eligible for surgical repair.Swiss Med Weekly.2007;137:337-40.

38- Crofts TJ, Park KG, Steele RJ, Chung SS, Li AK. A randomized trial of non-operative treatment for perforated peptic ulcer. N Engl J Med. 1989; 320:970-3.

39- Tuscott B, Withycombe JFR. Perforated peptic ulcer. An assessment of value of non-operative treatment. Lancet. 1950;13:894-6.

40- Schein M. To drain or not to drain? The role of drainage in contaminated and infected abdomen: an international and personal perspective. World J Surg. 2008;32:312-21.

41- Khan S, Rai P, Misra G. Is prophylactic drainage of peritoneal cavity after gut surgery necessary? A non- randomized comparative study from a teaching hospital.ICDR.2015;9(10):PC01-3

42- Cellan-Jones CJ. A rapid method of treatment of perforated duodenal ulcer: a randomized controlled trial. Ann Surg. 2002;235:313-9.

43- Graham RR. The treatment of perforated duodenal ulcer. Surg Gynecol Obstet. 1937:235-8.

44- Lunevicius $R$, Morkevicius $M$, management strategies, early results, benefits and risk factors of laparoscopic repair of perforated peptic ulcer. World J Surg. 2005;29:1299-310.

45- Whiteside OJ, Tytherleigh MG, Thrush S, Farouk R, Gilland R B. Intraoperative peritoneal lavage-who does it and why? Ann R Coll Surg Engl. 2005;87:255-8.

46- Pai D, Sharma A, Kanungo R, Jagdish S, Gupta A. Role of abdominal drain in perforated duodenal ulcer patients: a prospective controlled study. Aust NZ J Surg. 1999;69:210-3.

47- Jordan PH, Thornby J. Perforated pylorodudenal ulcer: long term results with omental patch closureand parietal cell vagotomy. Ann Surg. 1995;221:479-88.

48- Herbison SP, Dempsy DT. Peptic ulcer disease. Curr Probl Surg. 2005;42:346-454.

49- Nelson R, Edwards S, Tse B. Prophylactic nasogastric decompress after abdominal surgery. Cochrane Database Syst Rev (online). 2007;CD004929.

50- Simmen HP, Bataglia H, Kossmann T. Blaser J. Effect of $\mathrm{pH}$ in peritoneal fluid on outcome of aminoglycoside treatment in intra-abdominal infections. World J Surg. 1993;17:393-7.

51- Khan S, Gupta DK, Khan DN. Comparative study of three antimicrobial drug protocol (ceftriaxone, gentamicin or amikacin and metronidazole versus two antimicrobial drug protocol (ceftriaxone and metronidazole) in cases of intra-abdominal sepsis.KUMJ. 2005;3(9):55-63. 
52- Lam PW, Lam MC, Hui EK, Sun YW, Mok FP. laparoscopic repair of perforated duodenal ulcer, the three stitch Graham's patch technique. Surg Endosc.2005;19:1627-30.

53- Shah PH, Panchal HA. Acute perforation: clinical profile and our experience with operative outcome. Int Surg J. 2016;3(4):2227-32. 